\title{
Da representação ao controle: transformações do sindicalismo no decurso do desenvolvimento capitalista
}

\author{
From representation to control: transformations \\ of trade unionism within capitalist development
}

Valéria Lopes Peçanha*

\begin{abstract}
Resumo - Este artigo busca explicitar as transformações do sindicalismo no desenvolvimento histórico do capitalismo. Constituído como organização da classe trabalhadora para autodefesa do trabalho na ordem capitalista, o sindicalismo possui uma função econômica, em última instância, útil ao sistema capitalista. Se, por um lado, a luta sindical travada por salário, condições de trabalho e sobrevivência se faz necessária, ela imediatamente está limitada à perpetuação da exploração capitalista. Tais limites são abordados pela obra marxiana que, transcendendo-os, apontou o potencial revolucionário do sindicalismo. Na atual etapa histórica do capitalismo, presenciamos a redefinição da relação entre capital e trabalho: a ordem neoliberal implica na diminuição dos limites de barganha dos trabalhadores e na destruição das bases sobre as quais se ergueram as estratégias de luta que caracterizaram o movimento sindical ao longo do século XX. Diante deste ciclo descendente, cerne da crise sindical, reafirmase a necessidade do redirecionamento revolucionário e emancipatório do sindicalismo.
\end{abstract}

Palavras-chave: sindicalismo; capitalismo; capital; trabalho.

\begin{abstract}
This article aims to highlight the transformations of trade unionism within the historical capitalist development. Considered a working class organization, in view of the need to defend labor in the capitalist system, trade unionism performs a practical economic function by its nature of intervention in labor-capital relation. On one hand, the struggle of unions for better salaries, working conditions, and survival appears to be necessary; on the other hand, it maintains itself bound to the continuation of capitalist exploitation. Those limits are addressed in Marxian theory, which surpasses them, noting the revolutionary power of trade unionism. On the current stage of laborcapital relation, the neoliberal order entails a diminished bargaining power of workers, along with the destruction of the elements of agency and struggle that shaped trade unionism along the $20^{\text {th }}$ century. Facing this downward spiral, it reasserts the need of the unions' revolutionary and emancipatory redirection.
\end{abstract}

Keywords: trade unionism; capitalism; labor-capital relation.

\footnotetext{
* Professora de Sociologia do Colégio Pedro II. Mestre em Serviço Social e Especialista em Ensino de Sociologia pela Universidade Federal do Rio de Janeiro (UFRJ). Correspondência: Colégio Pedro II - Campus Niterói. Rua General Castrioto, Barreto, Niterói/RJ - Brasil. CEP: 24110-250. Email: <vallpecanha@gmail.com>
} 


\section{Introdução}

Os sindicatos, como sujeitos de ação da classe trabalhadora, estiveram profundamente atrelados às ideologias proletárias, tendo-as como matriz de sua orientação política. O sindicalismo, como base de organização do movimento operário, apresenta distintas variações quanto à sua concepção, natureza e funcionalidade, segundo as vertentes políticas pela qual se orientam os agentes políticos da classe trabalhadora em cada momento histórico. Este fato revela a determinação da práxis sindical pela práxis política e ideológica da classe trabalhadora (ALVES, 2000).

Dos arranjos entre as concepções ideológicas e as ações políticas do movimento operário, projetam-se tipos distintos de sindicalismo. Ao observarmos as formas de luta já desenvolvidas pela classe trabalhadora na defesa de seus interesses, encontramos o ludismo, o boicote, a greve e, por fim, os sindicatos. Cada uma destas formas de se organizar e agir representa uma forma singular da consciência e das práticas de luta das classes trabalhadoras, que se desenvolvem em face das relações sociais postas pela etapa de desenvolvimento do modo de produção capitalista com que se defronta.

Embora seja possível falar de uma natureza sindical, devemos levar em consideração que a apropriação feita do sindicalismo pelas classes sociais e seus segmentos através da história nos revela um caráter subjetivocoletivo. Este determina componentes centrais do movimento sindical: suas características, seus objetivos e, por consequência, seus resultados. Isto nos alerta para o fato de que a práxis política e ideológica da classe trabalhadora determina, em grande medida, a práxis sindical.

Caberá ao presente artigo analisar as transformações do sindicalismo decorrentes do progressivo empoderamento do capital que, escamoteado pela democracia participativa do Estado Burguês no século XX, passa a exercer controle institucional sobre as organizações da classe trabalhadora. Partindo deste referencial histórico, busca-se explicitar as tensões, os limites e as possibilidades do sindicalismo, que se formam como resposta e resultado mediante a uma complexa estrutura socioeconômica historicamente determinada, sobre a qual se ergue, assumindo formas específicas. Buscaremos explorar os nexos existentes entre a práxis político-ideológica e a práxis sindical, tendo em vista que estes constituem elementos centrais na direção que toma a luta de classes.

Para lançar luz sobre tais questões, são utilizadas fontes bibliográficas secundárias com enfoque na teoria marxista dos salários e nos apontamentos mais diretos de Karl Marx sobre as organizações sindicais, presentes principalmente nas obras Trabalho assalariado e capital e Salário, preço e lucro. 


\section{Os efeitos da intervenção dos sindicatos na relação entre capital e trabalho: contribuições da obra marxiana}

Em Trabalho assalariado e capital, Marx (2006) traz amplas contribuições sobre as relações sociais da produção capitalista, terreno em que se desenvolve a luta de classes, que se expressa, dentre outras formas, também através das lutas sindicais. Partindo da elucidação acerca do salário, afirma Marx (2006, p. 36) que este é o "nome particular dado ao preço da força de trabalho", utilizado como mediação na relação de troca que envolve trabalhadores e capitalistas, com suas distintas mercadorias. O modo de produção capitalista se fundamenta sobre a exploração do trabalho humano fonte da criação do valor - sob a forma de trabalho assalariado. Portanto, da conversão da força do trabalho em mercadoria "que seu possuidor, o assalariado, vende ao capital" para viver.

Marx (2008a) afirma que existem duas formas de capital empregadas na produção: o capital constante, que resulta do trabalho já acumulado anteriormente e encarnado nos próprios meios de produção - tais como a maquinaria, a matéria-prima, dentre outros -; e o capital variável, que é a parte do capital empregada em força de trabalho e que constitui a real força criadora de novos valores. Ele revela, portanto, a fonte da mais-valia capitalista, já que, embora o capitalista obtenha força de trabalho a custos socialmente estabelecidos segundo as leis de valor que regem as mercadorias - que, no caso da força de trabalho, constitui os salários -, a mercadoria força de trabalho, ao ser utilizada, revela seu caráter particular dentre todas as demais mercadorias: gerar valor.

No contrato firmado entre capitalista e trabalhador, a compra da força de trabalho é baseada numa remuneração fixada em função da medida de tempo de vida do trabalhador cedida ao capitalista - a jornada de trabalho. Durante essa medida de tempo, o capitalista adquire o direito de utilizar, na produção, todas as energias físicas e psíquicas do trabalhador (MARX, 2006). Tais limites fixados no tempo dedicado à produção, e não em seu volume, abriram precedentes para a intensificação do uso da força de trabalho e, portanto, para a alteração da composição orgânica do capital gerador de mais-valia. A alteração da relação entre capital constante (trabalho morto) e capital variável (trabalho vivo), utilizados na produção, incide em novas formas de extração de mais-valia: a absoluta e a relativa (MARX, 2006). Disto decorre que, quanto mais o capitalista empreende esforços pelo consumo cada vez mais eficaz desta força de trabalho na produção de mais-valia, e quanto mais exploração desta força criadora, maior o êxito do capitalista do ponto de vista dos lucros: força motriz do modo de produção capitalista (MARX, 2008b).

Estes elementos da relação entre capital e trabalho desenvolvidos na obra marxiana são de imensurável importância para a compreensão da sociedade capitalista e das relações sociais às quais todos os indivíduos 


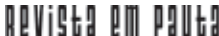

\} DA REPRESENTAÇÃO AO CONTROLE - PEÇANHA, V. L.\}

DOI: 10.12957/rep.2015.21051

estão submetidos. Considerando o salário como o preço da mercadoria força de trabalho, Marx (2006) aponta similaridades entre a determinação do preço da força de trabalho e as leis do mercado que regem as demais mercadorias. A determinação dos salários na obra marxiana se articula com base nos seguintes elementos: i) modo de acumulação; ii) oferta e demanda de força de trabalho; iii) composição demográfica da população; iv) parâmetros de subsistência; e v) organização política dos trabalhadores em sindicatos (ROWTHORN, 1980).

Segundo Marx (2006, p. 38), o que determina o preço de uma mercadoria "é a concorrência entre os compradores e os vendedores, a relação entre a solicitação e a disponibilidade, a oferta e a procura", tendo como referência o "custo de produção". Portanto, os salários podem se elevar ou mesmo se depreciar segundo a concorrência que se estabelece tanto entre a classe trabalhadora, para vender sua força de trabalho, quanto entre a classe capitalista, para comprá-la. Ambas as classes se contrapõem em barganha; uns para vender mais caro e outros para comprar mais barato. Contudo, o custo da produção da força de trabalho orbita ainda em torno do "custo necessário para conservar o operário como tal e para formar um operário" (MARX, 2006, p. 44).

Em decorrência do excesso de mão de obra, produzido pelas inovações das tecnologias de produção e de gestão do trabalho no desenvolvimento do modo de produção capitalista, são estabelecidos níveis salariais mínimos próximos ao nível de subsistência (MARX, 2006). Sendo assim, o salário seria determinado pelo valor dos artigos de primeira necessidade exigidos para produzir, desenvolver, manter e perpetuar a força de trabalho, tendo dois aspectos essenciais: i) o da natureza física, que implica no reconhecimento de um nível mínimo de subsistência necessário à produção e reprodução da força de trabalho; e ii) o da natureza histórica, ligado ao padrão tradicional de vida determinado culturalmente em cada tempo histórico (ROWTHORN, 1980, p. 192).

Deste modo, vemos que as condições de vida e empregabilidade da classe trabalhadora estão em estreita relação com a acumulação de capital, num processo de influência mútua que conforma o modo de acumulação historicamente correspondente. Uma vez que, segundo Marx (2006, p. 51), toda acumulação de capital provém do trabalho e é "trabalho acumulado", na medida em que o capital cresce, cresce também o trabalho assalariado e as possibilidades de melhoria das condições de vida da classe trabalhadora aumenta. Este crescimento no capitalismo, no entanto, traduzse numa "força hostil" ao trabalho vivo (o criador de toda riqueza), uma vez que o "aumento do poder do trabalho acumulado [morto] sobre o trabalho vivo significa o aumento do domínio da burguesia sobre a classe trabalhadora"1 (MARX, 2006, p. 51).

${ }^{1}$ Como exemplo desta relação, Marx (2006) ressalta que o aparato tecnológico do modo de acumulação pode gerar mão de obra excedente (como no processo de substituição de trabalho vivo por trabalho morto, desencadeado pela maquinaria). Por outro lado, pode ser incentivado como forma de suprir uma possível escassez de mão de obra. 


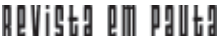

\} DA REPRESENTAÇÃO AO CONTROLE - PEÇANHA, V. L.\}

DOI: $10.12957 /$ rep.2015.21051

Neste sentido, os interesses do capital e do trabalho assalariado encontram-se "diametralmente opostos", em permanente disputa pela repartição da riqueza socialmente produzida. Na ordem capitalista, há uma lei de relação inversa entre salário e lucro; quanto mais o operário trabalha, "mais aumenta o capital produtivo". Este, por sua vez, consolidando-se em "divisão do trabalho" e "emprego da máquina", intensifica a "concorrência entre os operários" e a produtividade do trabalho, resultando em baixa dos salários (MARX, 2006, p. 64).

Em Salário, preço e lucro, Marx (2006) retoma e aprofunda a relação entre os salários e o processo de acumulação do capital. Em síntese, os movimentos entre estes limites ocorrem da seguinte maneira: em períodos de expansão, quando crescem a produção e a acumulação de capital, a demanda por mão de obra cresce mais rapidamente que a oferta; em consequência, os salários tendem a subir. Em períodos de recessão, quando a acumulação de capital se reduz, o exército industrial de reserva tende a aumentar, criando obstáculos à luta sindical através da concorrência entre trabalhadores empregados e desempregados que, diante da redução de seu poder de barganha, têm dificuldades de se opor à queda do nível dos salários ${ }^{2}$.

Ao longo da acumulação capitalista, as inovações técnicas no processo de produção têm apresentado a tendência de substituição do trabalho vivo pelo trabalho morto. Na medida em que os homens são substituídos por máquinas, reduz-se a dependência do capital em relação ao trabalho quanto à acumulação, crescendo a possibilidade de incremento da produtividade paralelamente ao aumento do exército industrial de reserva. As resoluções dos problemas de produtividade e lucratividade ocorrem em dois sentidos: o da mais-valia absoluta, quando o capital procura "extrair mais trabalho dos operários fazendo-os trabalhar mais e por mais tempo pelo mesmo salário", e o da mais-valia relativa, quando o capital reorganiza seus métodos de produção com vistas ao aumento da produtividade com menos mão de obra, impondo aos trabalhadores reduções do padrão de vida e de empregabilidade (ROWTHORN, 1980, p. 193).

Do ponto de vista da prática produtiva, a adoção da maquinaria na indústria têxtil, em substituição às demais formas organizatórias da produção, significou a "vitória do trabalho mecânico sobre o trabalho manual". Ou seja mediante um novo padrão de composição orgânico -, a vitória do capital sobre o trabalho que, entretanto, não ocorreu sem resistência (ENGELS, 2008). As dimensões sociais, políticas e culturais em que se estabelece a nova relação entre capital e trabalho engendram uma nova cons-

\footnotetext{
${ }^{2}$ Segundo Marx (2006), o estabelecimento de um nível mínimo é garantido pelo nível de subsistência exigido para que se mantenha a reprodução da população segundo as necessidades de reprodução do capital. Já o nível máximo de oscilação dos salários é determinado pela taxa de lucro dos capitalistas. Tais limites se consolidam enquanto prática através do salário mínimo.
} 


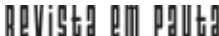

\} DA REPRESENTAÇÃO AO CONTROLE - PEÇANHA, V. L.\}

DOI: 10.12957/rep.2015.21051

ciência de classe, de onde resultam não apenas o mundo das mercadorias, mas o próprio Movimento Trabalhista (THOMPSON, 1987).

É através da ação sindical que os trabalhadores reivindicam os frutos da expansão capitalista. Disso decorre que o salário (rendimento do trabalho) e o lucro (rendimento do capital) são determinados através de lutas incessantes entre capital e trabalho, a depender do poder relativo de que gozam as partes. O poder de barganha dos trabalhadores ascende como elemento da determinação dos salários, fato que constitui sua limitação segundo a teoria marxista. Em suma, "toda ação sindical é de tipo reativo ou defensivo" (ROWTHORN, 1980, p. 196).

No confronto entre capital e trabalho, a tendência é que prevaleça o capital (embora não em termos absolutos), já que a ação dos sindicatos está sempre subjugada ao tamanho do exército industrial de reserva e à própria relação ditada pelo capital através do modo de acumulação. Assim, o sindicato atuaria em consonância com os limites postos pelo capital, tensionando-os em favor dos trabalhadores.

Entretanto, o aumento da grandeza do capital já constitui em si o correlato enfraquecimento do proletariado, que se vê em situação cada vez mais desvantajosa diante do patronato. Quanto maior o exército industrial de reserva, quanto mais severos forem os efeitos da acumulação de capital sobre a classe trabalhadora, menos capazes tendem a ser os sindicatos na defesa dos interesses dos trabalhadores. Isto porque a luta econômica dos sindicatos encontra seus limites nas próprias circunstâncias econômicas que a possibilitam. Ainda assim, ao longo do desenvolvimento do capitalismo, a luta sindical logrou êxitos consideráveis na defesa dos interesses dos trabalhadores, oscilando entre um posicionamento de elemento integrador da relação entre capital e trabalho, maximizando o próprio desenvolvimento do capital, e entre a transgressão de tais limites, quando se converteu em instrumento de contestação da ordem capitalista.

Desvendando o modo de funcionamento do capital, Marx pôde enxergar que as lutas empreendidas pelos sindicatos, embora necessárias, tinham graves limitações. Os elementos teóricos desenvolvidos por ele, já trazidos até aqui, apontam uma contradição essencial sobre o papel do sindicalismo na ordem capitalista. Frente às relações sociais de produção do seu tempo, Marx (2006) afirmou que as melhores condições de vida do trabalhador assalariado decorriam do crescimento do capital produtivo. Por um lado, o operário depende de que o capitalismo vá bem pra que ele obtenha condições de vida imediatamente razoáveis; por outro lado, quanto mais o trabalhador fortalece o capital, mais enfraquece a si mesmo. Portanto, seus interesses se assentam sobre uma permanente contradição.

Em suma, decorre disso que a luta sindical é contraditória em si. Quando esta luta se restringe ao plano econômico, como no caso das reivindicações salariais, pode significar estar lutando contra a própria classe trabalhadora, uma vez que colabora para perpetuação da ordem capitalista.

EM PAUTA, Rio de Janeiro - 2 Semestre de 2015- n. 36, v. 13, p. 43 - 62 


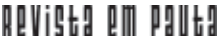

\} DA REPRESENTAÇÃO AO CONTROLE - PEÇANHA, V. L.\}

DOI: 10.12957/rep.2015.21051

Quando esta luta se amplia para o plano político, como luta pela superação do capital, pode, neste caso, resultar na luta por sua própria superação já que, extinto o sistema, tal instituição possivelmente deixaria de existir.

Neste sentido, Marx (2006, p. 134) busca desvendar "até que ponto, na luta incessante entre o capital e o trabalho", há possibilidade de êxito da classe trabalhadora. Historicamente, pode-se reconhecer a "relação de forças" entre capital e trabalho como um dos fatores que determinam as condições em que ocorre a acumulação do capital. Entretanto, segundo Marx (2006, p. 140), "com o desenvolvimento das forças produtivas do trabalho, acelera-se a acumulação do capital" sem que ocorra uma "absorção de trabalho" na mesma proporção; esta "aumenta numa proporção constantemente decrescente com relação ao aumento do capital".

Uma vez tendo desvelado o sindicato como uma instituição eivada das contradições do capital e realizado sua crítica às lutas imediatamente econômicas do sindicalismo, o autor defende que a classe operária deve evitar "exagerar, a seus próprios olhos, o resultado final dessas lutas diárias", voltando-se a uma luta não contra os efeitos, mas "contra a causa desses efeitos", luta que se lance rumo à "abolição do sistema assalariado" (MARX, 2006, p. 141).

Os sindicatos trabalham bem como centros de resistência contra as usurpações do capital. Falham em alguns casos, por usar pouco inteligentemente a sua força. Mas são deficientes, de modo geral, por se limitarem a uma luta de guerrilhas contra os efeitos do sistema existente, em lugar de empregarem suas forças organizadas como alavanca para a emancipação final da classe operária, isto é, para a abolição definitiva do sistema de trabalho assalariado. (MARX, 2006, p. 142).

Segundo Marx (2006, p. 137), no plano da "luta puramente econômica, o capital é a parte mais forte" da correlação de forças entre capital e trabalho. A partir de tal conclusão, ele aponta o sentido da luta pela superação da ordem capitalista como caminho desejável para as lutas sindicais.

Ao longo do século XIX, a Europa vivenciou uma etapa de redimensionamento dos Estados que culminou com a vitória da burguesia, garantindo a liderança política necessária ao pleno desenvolvimento do Estado Burguês e do capitalismo. Neste processo, tornou-se evidente o fortalecimento do Estado Burguês, refletido no progressivo aumento de sua importância no escopo geral das lutas de classe. Passou, assim, a desempenhar um papel central na consolidação da acumulação de capital e na consolidação do padrão de vida mínimo concedido aos trabalhadores. Nesta nova "era" da ordem capitalista, o Estado se converteu em instrumento burguês de dominação da classe trabalhadora (ENGELS, s/d).

A institucionalidade característica do Estado Burguês ampliou o controle sobre a sociedade civil através da formação de uma dispendiosa e 


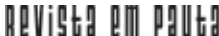

\} DA REPRESENTAÇÃO AO CONTROLE - PEÇANHA, V. L.\}

DOI: 10.12957/rep.2015.21051

burocratizada máquina estatal. O desenvolvimento das instituições políticas burguesas, tais como os aparelhos burocrático e militar, incidiram sobre a luta de classes, transformando o poder político das classes e suas formas de reivindicação. Com a consolidação do sufrágio como principal mecanismo de participação política no capitalismo democrático, fruto da persistência e do avanço das formas organizatórias das lutas proletárias, na segunda metade do século XIX formavam-se os grandes partidos de massa europeus. Tais mudanças da práxis política da classe trabalhadora se refletiram sobre as organizações sindicais sob a forma da transição do sindicalismo de ofício para a formação do new unionism, o moderno sindicalismo de massas (HOBSBAWM, 2000).

A necessidade de conquista do poder político pelas massas trabalhadoras para a conquista definitiva da emancipação social tem, na democracia política do capital ${ }^{3}$, um novo espaço de disputa entre classes (PRZEWORSKI, 1988). A despeito da resistência de certos grupos contrários à participação política dos trabalhadores nos moldes estabelecidos pela ordem burguesa (tal como os anarquistas), a disputa pelo poder estatal se consolidou progressivamente como estratégia de luta das classes trabalhadoras. De fato, a questão da participação política da classe trabalhadora na democracia capitalista influenciou não somente o movimento socialdemocrata alemão, mas também o movimento trabalhista inglês. Cabe lembrar, ainda, que a democracia capitalista ganhava dimensão prática nos países em que a burguesia havia reunido condições político-econômicas para redimensionar o Estado Burguês, adequando-o à nova etapa de desenvolvimento do capital.

A consolidação da forma democrática do Estado Burguês promoveu um redimensionamento da relação entre capital e trabalho, evidenciado na própria necessidade de representação da classe trabalhadora. Trata-se de uma nova forma de integração dos indivíduos à estrutura político-econômica, transformada através da estrutura de relações de representação que possibilitaria a passagem gradual da subordinação formal para a subordinação real do trabalho ao capital. Desta forma, a democracia burguesa incidiu sobre a estrutura de classes, causando impactos nas formas organizatórias da classe trabalhadora. Segundo Przeworski (1988, p. 49):

O parlamento é uma instituição representativa: recebe indivíduos, não massas. Uma relação de representação é assim imposta sobre a classe pela própria natureza das instituições capitalistas democráticas. As massas não agem diretamente na defesa de seus interesses; delegam essa defesa. Isso é verdade tanto para os sindicatos quanto para os partidos: o processo de barganha coletiva situa-se tão distante da experiência diárias das massas quanto as eleições. Os líderes tornam-

\footnotetext{
${ }^{3}$ Ao possibilitar a participação política das massas, o Estado burguês preservou seu autoritarismo característico, pois, a despeito da democracia representativa que se instaurava como institucionalidade política, sua base econômica permaneceu sendo uma "ditadura do capital sobre o trabalho".
} 


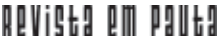

\} DA REPRESENTAÇÃO AO CONTROLE - PEÇANHA, V. L.\}

DOI: 10.12957/rep.2015.21051

se representantes. Massas representadas por líderes: esse é o modo de organização da classe trabalhadora dentro das instituições capitalistas. Dessa maneira, a participação des-mobiliza as massas.

A lógica de participação pela via das relações de representação se impôs sobre os sindicatos, atrelando-os ao corpo burocrático do Estado Burguês. Neste novo modelo estrutural, o sindicalismo passa a requerer um aparato permanente, cujos efeitos sobre a dinâmica de funcionamento dos sindicatos pode ser aferida pela transformação dos militantes da luta proletária em burocratas da estagnação sindical (PRZEWORSKI, 1988). Trata-se da hegemonia do capital sobre o trabalho que se reflete na mobilização do Estado - instância máxima do poder político da sociedade capitalista , através do qual exerce o controle sobre o trabalho. Portanto, na relação entre Estado e sindicatos, encontramos reproduzida a relação entre capital e trabalho.

Estas eram as condições gerais em que se desenvolveram as lutas de classe no início do século XX. Num período histórico em que a proposta revolucionária perdia força e parecia cada vez mais distante, os movimentos sindicais trilharam os caminhos da participação política circunscrita aos limites da democracia burguesa com uma perspectiva cada vez mais reformista. Assim, encontramos os exemplos históricos nas mudanças dos rumos tomados pelo movimento social-democrata alemão e pelo trabalhismo inglês.

Vemos, portanto, que na passagem do século XIX para o século XX evidenciou-se um expressivo crescimento da importância do Estado na regulação da produção capitalista. Por um lado, como a ascensão da perspectiva reformista nos mostra, o Estado tornava-se alvo de disputa pelas classes em luta, sendo, inclusive, relativamente moldado em função da correlação de forças dessas classes. Por outro lado, em função da hegemonia burguesa exercida sobre o Estado, todo fortalecimento do mesmo garantiu o aumento da hegemonia do capital sobre o trabalho. Independente da feição de neutralidade assumida, o Estado permanece sendo instrumento de dominação capitalista. A importância do Estado na "intervenção do sistema político no mercado de trabalho" revela o potencial do poder político para a ordem capitalista que, naquele momento, assume a função de controle e administração do excedente (VIANNA, 1983, p. 74).

Deste modo, a institucionalização do sindicalismo traz, em sua contraface, o enfraquecimento do trabalho diante do capital. Uma vez que o sindicato é tornado instituição do sistema político da ordem capitalista, o movimento sindical tem sua atuação sobre o modo de produção redefinida: sua progressiva integração ao Estado fortalece a dominação capitalista. Trata-se de uma redução de seu potencial, muito embora não seja a completa anulação do poder da atuação do sindicalismo sobre a ordem política e econômica do capital em defesa do trabalho. 
Considerando que a expansão do capitalismo se deu sempre sobre a destruição das resistências dos trabalhadores que, quando não foram eliminadas passaram por ressignificações devastadoras de seus sentidos originários, também a cooptação do sindicalismo se tornaria elemento crucial para a propulsão do controle do trabalho que se tornava exigência da ordem capitalista em expansão. Nesse sentido, se tomarmos em consideração que, na ordem capitalista, o Estado é convertido em instrumento da dominação burguesa, uma vez circunscrita à institucionalidade do Estado Burguês, o sindicalismo passa de instrumento legítimo de organização dos trabalhadores à instituição submetida ao próprio capital - portanto, à força à qual deveria se opor. Em decorrência disso, justamente aqueles efeitos imediatos e benéficos exercidos pela ação sindical sobre a ordem capitalista - sobre os quais Marx havia atentado - são aprofundados.

No espaço aberto pela socialização dos trabalhadores, na vivência da exploração característica da produção capitalista, a ação sindical apresenta um duplo aspecto: como "meio de dominação" e como meio de "emancipação". Se, por um lado, o sindicalismo assume uma dimensão de funcionalidade no processo produtivo capitalista, por outro lado, as necessidades de defesa do trabalho se aprofundam. O sindicalismo se constitui como uma instância de reconstrução da esfera de poder do trabalhador. Nela, o trabalho se representa frente ao capital com vistas à defesa de suas necessidades, reunindo os clamores dos indivíduos num sujeito político coletivo relativamente autônomo. Esta instância pode, inclusive, se lançar rumo a um horizonte de atuação reivindicatória mais ampla, contribuindo para a luta emancipatória. Portanto, apesar de seu caráter estrutural, que o relaciona imediatamente às reivindicações de cunho econômico, é possível que o sindicalismo oriente sua ação à disputa política revolucionária com vistas à superação do capitalismo.

\section{Capitalismo monopolista e sindicalismo: a ampliação do controle patronal sobre o trabalho}

Ao final do século XIX, com o acúmulo de capital proveniente da etapa concorrencial, desencadeava-se uma nova etapa na "economia mundial capitalista" - o capitalismo monopolista. A corrida pela valorização do capital gera um deslocamento para novas áreas de exploração - tanto no que diz respeito ao espaço geográfico quanto aos setores econômicos -, ao qual se sucedem ciclos de expansão e esgotamento. Estes deslocamentos constituem-se como novas estratégias de valorização do capital, que possibilitam, ainda que de modo temporário, a recomposição da taxa de lucro através da intensificação da extração de mais-valia relativa e/ou absoluta. Ambas consistem na recuperação da taxa de lucro a partir da intensificação da exploração do capital variável, dos gastos com a remuneração do trabalho (salários). 


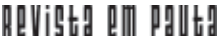

\} DA REPRESENTAÇÃO AO CONTROLE - PEÇANHA, V. L.\}

DOI: 10.12957/rep.2015.21051

Embora tanto na produção industrial dos países centrais, quanto na produção de matéria-prima dos países periféricos, a principal medida de contenção da queda tendencial da taxa de lucro tenha sido o aumento da produtividade do trabalho, em longo prazo a assimetria entre o aumento da produtividade dos países centrais e a estagnação nos países periféricos se revelou durante as primeiras décadas do século XX. Assim, apresentouse sob a forma de uma crise econômica mundial, iniciada durante a Primeira Guerra Mundial e deflagrada entre os anos de 1929 e 1932 (MANDEL, 1985). O desfecho da competição capitalista revelaria novas formas de exploração e dominação. Dentre elas, o "surto armamentista internacional" ocorrido nas décadas de 1940 e 1950 - como a Segunda Guerra Mundial e a Guerra da Coréia -, o deslocamento do padrão de exportação dos países imperialistas para bens de capital fixo e a constituição de "um novo setor de bens de consumo" - do qual fazem parte a "produção automobilística e o início da produção de aparelhos elétricos" - constituem as principais expressões (MANDEL, 1985, p. 133).

Estes acontecimentos marcam a "transição do imperialismo clássico para o capitalismo tardio", etapa em que a "pressão para elevar a taxa de lucros" geraria, na trilha aberta pela "terceira revolução tecnológica", uma nova "onda longa expansionista" que se estenderia de 1945 a 1965. Neste processo, ocorre uma "tendência geral à intensificação de todas as contradições do modo de produção capitalista" (MANDEL, 1985, p. 139). Resulta, assim, numa etapa da acumulação capitalista que traz em seu cerne uma "avançada organização do trabalho mediante crescimento de vulto na produtividade do trabalho". Nesta, a estratégia de valorização do capital incide sobre o controle do trabalho, promovendo uma reforma empresarial ampla sustentada pela apropriação burguesa da ciência, canalizada para o desenvolvimento capitalista.

O monopólio burguês sobre as revoluções científico-tecnológicas canalizadas em função de seu aproveitamento produtivo -, através da subdivisão taylorista do trabalho, recriou as condições da valorização do capital, possibilitadas pela "departamentalização técnica" que caracterizou a "gerência moderna". A via da organização científica do trabalho possibilitou a apropriação do controle patronal do processo de trabalho, revolucionando os métodos patronais de dominação através do maior aproveitamento da força de trabalho empregada na produção. A plena instauração do modo de produção fordista necessitou de uma formação correspondente no âmbito da regulação estatal. Esta se conformaria após a década de 1930 quando, em resposta à crise, seria configurado um novo arranjo político-econômico capaz de "regulamentar" as condições necessárias à reprodução capitalista. Neste processo, "O fordismo se aliou firmemente ao keynesianismo" (HARVEY, 2009, p. 125).

Sob o fordismo, portanto, uma "nova organização social", pautada na "configuração das forças produtivas" e orientada para a "racionalização 


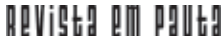

\} DA REPRESENTAÇÃO AO CONTROLE - PEÇANHA, V. L.\}

DOI: 10.12957/rep.2015.21051

do trabalho" e a organização planejada da economia, lentamente se conformaria em correspondência à ascensão, no plano mundial, dos Estados Unidos como superpotência capitalista. Este modelo criou o advento da "diferenciação da força de trabalho" com base na desigualdade das condições de exploração às quais se submetiam os trabalhadores.

A partir do fordismo, as concessões burguesas se voltaram à reconstrução das relações entre capital e trabalho, originando um novo tipo de legitimidade. Esta foi construída pelas vias do sindicalismo através da interlocução com o espaço privilegiado de empregabilidade pertencente aos trabalhadores industriais, brancos, homens e sindicalizados - segmento detentor das benesses trazidas pela ampliação do acesso aos bens produzidos na sociedade do consumo de massa (BRAGA, 1995).

Acerca dos efeitos do fordismo sobre o sindicalismo nos "anos dourados" do desenvolvimento capitalista, Antunes (1999, p. 39) afirma que:

[...] foi se verificando durante o fordismo o processo de integração do movimento operário social-democrático, particularmente dos seus organismos de representação institucional e política, o que acabou por convertê-lo numa espécie de engrenagem do poder capitalista.

Assim, desencadeia-se um processo de centralização do poder político pelo Estado Burguês, que encontra no controle institucional dos sindicatos a ferramenta necessária para o esvaziamento do poder operário. Neste processo, o sindicalismo redimensiona sua representatividade; passa da orientação de suas ações pelos legítimos enfrentamentos dos trabaIhadores em oposição ao capital, para a colaboração com o capital em troca da "redistribuição dos ganhos de produtividade" sob a forma de salários - possibilitando a ampliação da participação dos trabalhadores no consumo de massa.

Segundo Bihr (1991), no que tange ao sindicalismo, é possível afirmar que houve uma integração do movimento operário social-democrata, no fordismo, à ordem capitalista. Redefiniram-se, desta maneira, as instituições de representação da classe trabalhadora como instrumentos da engrenagem capitalista, atreladas e controladas pelo Estado Burguês. Portanto, no pacto fordista as organizações políticas da classe trabalhadora se firmam como instituições de intermediação entre capital e trabalho, sob a tutela oficializadora do Estado, que assume uma feição "arbitral" superficial, permanecendo de fato em favor da burguesia (ANTUNES, 1999; BIHR, 1991).

Esta era a estratégia capitalista de persuasão do movimento operário social-democrata ao abandono de seu "projeto societário autônomo" e em troca da integração ao sistema. Este fato acabou convertendo-o em "verdadeiros cogestores do processo global de reprodução do capital" (BIHR, 1991 , p. 67). Neste processo, o sindicalismo se transformou em ferramenta 


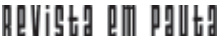

\} DA REPRESENTAÇÃO AO CONTROLE - PEÇANHA, V. L.\}

DOI: 10.12957/rep.2015.21051

de controle sobre os trabalhadores, tendo, para isso, se utilizado do tradicional papel desta instituição na representação dos trabalhadores frente ao capital. Consequentemente, os sindicatos assumiram uma pauta política reivindicatória circunscrita aos limites previstos pelo Welfare State, orientada às lutas por melhores condições de trabalho, por aumentos salariais e pela ampliação da seguridade.

Diante da cooptação burguesa, os sindicatos assumem uma lógica de funcionamento burocratizante, mais autônoma com relação à sua base e mais dependente com relação ao Estado. Esta lógica faz com que os trabalhadores passem a ter de lutar constantemente pelo seu próprio sindicato, para que este tenha uma conformação legítima. O movimento sindical reduz sua atuação, assumindo um viés previsível, economicista, legalista e submisso à institucionalidade burguesa. Difundindo, desta maneira, junto à classe trabalhadora uma visão paternalista do Estado e do patronato, fato que amplia a capacidade da ordem burguesa de manter sua estabilidade política e econômica.

\section{Neoliberalismo, reestruturação produtiva e acumulação flexível: novos patamares de exploração do trabalho}

Ao início da década de 1970, a manifestação da reemergência da crise estrutural do capital punha fim ao longo período de acumulação capitalista sob o padrão fordista, iniciando uma etapa de corrosão do aparato estatal conformado, de reconfiguração do padrão de acumulação e de reordenamento dos mecanismos de controle do trabalho. Trata-se de uma "reorganização do capital com vistas à retomada do seu patamar de acumulação e ao seu projeto global de dominação", que se expressa numa "nova configuração da estrutura capitalista de produção" (ANTUNES, 1999, p. 31).

Sob a égide do capitalismo monopolista, o desenvolvimento da produção industrial no Oriente engendraria novas práticas produtivas que exerceriam influência sobre o padrão de acumulação fordista em diversos aspectos. Originaram-se, então, novas práticas flexíveis - cujos elementos superavam o entrave característico do fordismo, a rigidez da produção. Foram, então, a resposta necessária à superação da crise de produtividade do padrão fordista de acumulação, consagrando-se como alternativa para a recomposição da valorização do capital. Assim, a "via japonesa de expansão e consolidação do capitalismo monopolista industrial" constituiu uma organização produtiva dotada de alta "capacidade de extração intensificada do trabalho", derivada da combinação das "formas relativas e absolutas da extração de mais-valia", conformando o toyotismo (ANTUNES, 1999, p. 54).

A adoção deste modelo flexível pelos países ocidentais "receptores" deu-se mediante um processo de adaptação, em que um desen- 


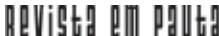

\} DA REPRESENTAÇÃO AO CONTROLE - PEÇANHA, V. L.\}

DOI: 10.12957/rep.2015.21051

volvimento desigual e combinado, constituído pela confluência dos modelos fordista e toyotista, originou formações híbridas conforme as condições de exploração presentes nos novos territórios. Neste processo, passam a coexistir, no ordenamento da produção capitalista, múltiplas formas de racionalização do processo de trabalho. Estas não se contrapõem umas às outras, mas evidenciam a "passagem para um regime de acumulação" novo, que denominamos acumulação flexível (ANTUNES, 1999, p. 54).

Os efeitos da mundialização do capital e da reestruturação produtiva sobre a composição da classe trabalhadora constituem mudanças. Estas aparecem na força de trabalho empregada na indústria sob a confluência de tendências opostas e complementares, entre reduções do contingente de trabalhadores nas regiões centrais do capitalismo e sua expansão nas regiões periféricas, no decurso dos "movimentos de relocalização industrial". A estes fatores somam-se, em todas as frentes de industrialização do capitalismo mundializado, as tendências de: i) redução do trabalho preconizada pela lean production e viabilizada pela Terceira Revolução Tecnológica; e ii) subcontratação decorrente da "fragmentação sistêmica", conformando um mercado de trabalho de caráter "dual" e complementar, formado por "centro" e "periferia", no que tange às formas de trabalho da produção capitalista (ALVES, 2000).

Neste sentido, origina-se uma "fragmentação" de classe formada pela corrosão da "classe operária tradicional", "do crescimento dos assalariados" do setor de serviços e a "proliferação do trabalho assalariado precário". Simultaneamente, é acompanhada pelo crescimento do "desemprego estrutural" quando, no capitalismo mundializado, o contingente de trabalhadores excedentes se transforma em contingentes permanentemente excluídos da perspectiva de empregabilidade (ALVES, 2000).

Deste modo, constitui-se uma "nova ofensiva do capital na produção", que articula "coerção capitalista e consentimento operário", reconstituindo de modo controlado o potencial criativo e participativo do trabalho (ALVES, 2000). Temos aqui a superação definitiva da subsunção formal pela subsunção real do trabalhador ao capital, elemento que implica a ampliação da exploração do trabalho ao possibilitar a captura da subjetividade do trabalhador para uma maior participação do processo produtivo. Este processo de reformulação da ordem capitalista encontra seu ponto nodal no Estado Burguês, cujo caráter interventor é redimensionado em função da valorização do capital.

A "reestruturação produtiva do capital" constituiu a "base material" do projeto neoliberal. Além disso, sua gradativa assimilação pelo aparelho de dominação estatal conformou o Estado Neoliberal (ANTUNES, 1999, p. 58). A intervenção política na economia, engendrada pelo Estado Neoliberal, denota novas condições, nas quais se desenvolve a luta de classes. O confronto entre os poderes dominantes da burguesia e as organizações coletivas da resistência operária revela, neste momento histórico, uma corre- 


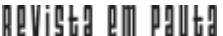

\} DA REPRESENTAÇÃO AO CONTROLE - PEÇANHA, V. L.\}

DOI: 10.12957/rep.2015.21051

lação de forças assimetricamente desfavorável ao trabalho. Isto propicia as condições para a consolidação de uma expropriação dupla do poder do trabalho $(T)$ pelo capital $(K)$, que consiste numa ferramenta de controle do fator central da produção capitalista: os sujeitos do trabalho. Deste modo, toda organização política engendrada pelo Estado Burguês tem por finalidade promover tal expropriação através do controle do trabalho, com vistas a uma interferência adequada à plena realização da economia capitalista.

O primeiro aspecto da expropriação decorre das leis econômicas do modo de produção capitalista, já apontadas por Marx (2008b) no desvendar da acumulação de capital: a realização da exploração do trabalho gera o aumento progressivo do poder do capital correlato a um correspondente enfraquecimento do poder do trabalho. Assim, quanto mais o trabalhador enriquece o capitalista, mais miserável se torna.

Há aqui uma redução dos poderes do trabalho que nascem dele, mas que se transferem para o capital, em conformidade com as relações sociais da ordem do capital. Estes poderes se estendem para além da forma econômica, já que engendram formas políticas e culturais correspondentes - que conformam novos aspectos da expropriação. Neste sentido, o segundo aspecto da expropriação do poder dos trabalhadores pelo capital consiste no sufocamento sistemático de suas forças políticas em todas as suas manifestações sindicatos, partidos, movimentos sociais e ideologias proletárias. Isto acontece uma vez que os trabalhadores se utilizam de tais organizações para interferir na ordem capitalista em defesa de seus interesses.

Em função da hegemonia burguesa sobre a sociedade capitalista, a capacidade de organização do capital é inversamente proporcional à da classe trabalhadora. A redefinição progressiva das fronteiras da exploração do capital sobre o trabalho, no decurso do desenvolvimento capitalista, agrava a assimetria da correlação de forças entre as classes sociais, que constitui o pilar de sustentação da sociedade capitalista. O avanço do capital sobre o trabalho em seu desdobramento contínuo se converte em novas forças exercidas sobre a classe trabalhadora, sem que os tradicionais mecanismos de representação da mesma consigam criar correspondentes estratégicos. Ao mesmo tempo, tal discrepância se converte em ameaça à própria ordem capitalista.

Conforme Marx (2008a) desvela em O capital, os capitalistas buscam intensificar a exploração capitalista do trabalho segundo a tríade duração, intensidade e capacidade produtiva. Nesse sentido, há um aumento da assimetria de poder com que se defrontam capital e trabalho, uma desigualdade progressiva sobre a qual se assenta a relação entre capital e trabalho. Segundo Luxemburgo (apud ROSDOLSKY, 2001, p. 247), esta tendência só é superável pela "transformação socialista da sociedade". Isto porque, 
A produção capitalista não pode avançar um passo sem reduzir a participação dos trabalhadores no produto social. Com cada inovação técnica, com cada melhora das máquinas, com cada aplicação nova do vapor e da eletricidade na produção e no transporte, diminui a participação dos trabalhadores no produto e aumenta a dos capitalistas.

O avanço progressivo do capital sobre o trabalho constitui o cerne do sistema capitalista. Na medida em que se realiza, avançando sobre seus próprios limites, revela seu caráter destrutivo: a relação contraditória entre capital e trabalho constitui, simultaneamente, crise e estrutura do sistema capitalista. Os sujeitos coletivos se defrontam como ameaça mútua, orientando-se à defesa de seus interesses particulares ao mesmo tempo em que conformam uma universalidade, a sociedade capitalista.

Marx (2011), nos Grundrisse, aponta a contradição essencial do capitalismo: a autocontradição do capital. Esta não necessariamente exclui a possibilidade da revolução, mas sem dúvidas redefine qualquer perspectiva de ação política que se pretenda revolucionária - resulta, portanto, numa complexificação necessária da compreensão sobre a ordem capitalista. A noção do sujeito automático do capital, desenvolvida por Marx (2011) nos Grundrisse, longe de anular as contradições postas entre sujeitos que compõem o capital e os desdobramentos de seus embates, recolocam-nas num novo patamar de compreensão: a contradição entre capital e trabalho não é, em si mesma, sinônimo de revolução, mas demanda a construção de uma perspectiva revolucionária capaz de superar a lógica do capital.

Com base nessas considerações, é preciso atentar à contradição entre as classes sociais do capitalismo, no que tange a seu caráter aparente e seus aspectos mais essenciais. Na ordem capitalista, o trabalho partilha interesses com o capital, uma vez que, "no capitalismo, a classe trabalhadora está submetida de antemão ao poder econômico do capital, e sua 'parte' é definida conforme a "parte do capital'" (ROSDOLSKY, 2001, p. 239). Entretanto, devemos observar que os sujeitos do capitalismo são dotados de intencionalidades derivadas dos lugares distintos que ocupam no sistema explorador e explorado. Neste sentido, seus interesses são: i) opostos, porque disputam permanentemente a distribuição da riqueza socialmente produzida sob forma de salário ou lucro; e ii) complementares, porque, mesmo na disputa entre si pela apropriação do valor, permanecem impulsionando a produção capitalista. Assim, podemos perceber que as intencionalidades próprias das classes, as visões particularistas do processo em que se inserem, imediatamente estão circunscritas ao caráter "automático" das relações sociais do capital, podendo ser facilmente assimiladas pela sua universalidade.

No que tange às assimetrias que perpassam a relação entre capital e trabalho, Marx (2011, p. 705) aponta uma tendência expansiva, tendo em vista que "as condições objetivas do trabalho assumem uma autonomia cada vez mais colossal, que se apresenta por sua própria extensão, em rela- 


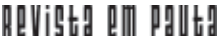

\} DA REPRESENTAÇÃO AO CONTROLE - PEÇANHA, V. L.\}

DOI: 10.12957/rep.2015.21051

ção ao trabalho vivo". Trata-se de uma tendência de progressivo esvaziamento do poder do trabalho em favor do capital. Este movimento se revela tanto na teoria dos salários, quanto na teoria do exército industrial de reserva e nas correlatas teorias da superpopulação, constituindo a força motriz de múltiplos fenômenos provenientes desta lei tendencial.

Neste sentido, ao final do século XX, o sindicalismo de massas atinge o seu esgotamento na medida em que o capital logra êxito na fragmentação da identidade da classe trabalhadora, atingindo seu ponto nevrálgico: o movimento operário. Segundo Harvey (2009, p. 141), a acumulação flexível "se apoia na flexibilidade dos processos de trabalho, dos mercados, dos produtos e padrões de consumo", refletindo-se sobre a organização do trabalho, principalmente através de "níveis relativamente altos de desemprego estrutural" e "retrocesso do poder sindical". Este último elemento se havia constituído durante o longo período de estabilidade da ordem capitalista, possibilitado pela aliança entre o padrão de acumulação fordista e o Estado de Bem-Estar Social. Portanto, o poder sindical, como pilar de sustentação do sistema capitalista, assume uma centralidade de novo tipo.

Os sindicatos, em função do seu potencial jurídico de representação coletiva do trabalho, transformam-se em instrumentos de ratificação formal da flexibilização das relações de trabalho, da corrosão dos salários, das reformulações contratuais e das novas formas de intensificação da exploração do trabalho impostas pelo patronato e pelo Estado.

No contexto da ordem neoliberal, a corrosão do poder operário resulta no predomínio do sindicalismo corporativista. Sob tal lógica, amplas parcelas do movimento sindical compactuam com um falso apagamento do conflito de classes. Ao privilegiar uma ação propositiva, pretensamente conciliadora dos interesses das classes, coopera com o avanço do capital sobre o trabalho. Já se configura, portanto, como um momento de crise do sindicalismo na medida em que sua ação o aproxima de seu próprio abismo, decorrente da fragmentação destrutiva da classe que ele representa. Quando deixa de perseguir os interesses da classe, abrindo caminho para o capital, resulta em instrumento inútil à classe trabalhadora e subserviente àquela força que deveria enfrentar, atuando vilmente como mecanismo de controle do trabalho. Neste sentido, a burocracia que o sustenta é a mesma que o destrói.

Esta mudança da orientação político-ideológica dos sindicatos decorre da crise do sindicalismo, sobre o qual se constitui uma resposta fácil e imediatamente possível que, entretanto, colabora para o seu aprofundamento. Segundo Alves (2000), é possível apontar a existência de dois aspectos da crise do sindicalismo: o socioinstitucional - que se reflete na crise de representatividade dos sindicatos -, e o político-ideológico - caracterizado por uma expressiva corrosão da práxis classista e pelo avanço do neocorporativismo. 


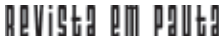

\} DA REPRESENTAÇÃO AO CONTROLE - PEÇANHA, V. L.\}

DOI: 10.12957/rep.2015.2105

É uma crise do sindicalismo moderno que deve ser apreendida não apenas em seus aspectos socioinstitucionais, com o declínio de representação sindical (o que é salientado pelos sociólogos e economistas), mas, notadamente, em seus aspectos político-ideológicos (o surgimento de estratégias neocorporativas, de colaboração com o capital). Essas estratégias caracterizam uma crise do sindicalismo de novo tipo, de cariz estrutural (em que são postos, de modo pleno, os limites de uma práxis sócio-histórica que permanece meramente no interior da lógica mercadoria). (ALVES, 2000, p. 83).

Na passagem do século XX ao século XXI, presenciamos, no contexto da crise estrutural do capital e da falência dos mecanismos de regulação da relação entre capital e trabalho, a redução da ação sindical nos limites do controle do trabalho. Além disso, defrontamo-nos com a urgência de um redimensionamento político-ideológico dos mesmos a fim de que sejam retomadas as perspectivas emancipatórias da classe trabalhadora.

O reconhecimento dos limites da luta em defesa do trabalho, que caracteriza a luta de classes, não implica em reconhecê-la como desnecessária. Ao contrário, ela expressa necessidades imediatas da classe trabaIhadora em garantir sua subsistência e demais interesses, ainda que distantes das aspirações revolucionárias. Na medida em que se agrava a assimetria de forças entre as classes partes componentes da ordem capitalista, a luta de classes faz-se necessária como forma, inclusive, de defesa à própria sobrevivência dos trabalhadores no modo de produção capitalista.

Conforme indica a obra marxiana, embora a defesa do trabalho permaneça necessária em face da assimetria na correlação de forças cumulativa em favor do capitalista, a luta de classes não é revolucionária em si mesma, sendo necessário que ultrapasse os limites imediatamente impostos pelo capital, de modo a atingir um potencial emancipatório. 


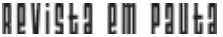

\} DA REPRESENTAÇÃO AO CONTROLE - PEÇANHA, V. L.\}

DOI: $10.12957 /$ rep.2015.21051

\section{Referências}

ALVES, G. O novo (e precário) mundo do trabalho. Reestruturação produtiva e crise do sindicalismo. São Paulo: Boitempo Editorial. 2000.

ANTUNES, R. Os sentidos do trabalho. Ensaios sobre a afirmação e a negação do trabalho. São Paulo: Boitempo Editorial. 1999.

BIHR, A. Da grande noite à alternativa: o movimento operário europeu em crise. São Paulo, Boitempo. 1991.

BRAGA, R. Luta de classes, reestruturação produtiva e hegemonia. In: KATZ, C.; BRAGA, R.; COGGIOLA, O. (org.). Novas tecnologias: crítica da atual reestruturação produtiva. São Paulo: Xamã. 1995.

ENGELS, F. A situação da classe trabalhadora na Inglaterra. São Paulo: Boitempo. 2008.

. A origem da família, da propriedade privada e do Estado. In: MARX, K.; ENGELS, F. Obras escolhidas, v. 3. São Paulo: Alfa-Omega. s/d.

HARVEY, D. Condição pós-moderna. São Paulo: Edições Loyola. 2009.

MANDEL, E. Capitalismo tardio. São Paulo: Nova Cultural. 1985.

MARX, K. Trabalho assalariado e capital e Salário, preço e lucro. São Paulo: Ed. Expressão Popular. 2006.

O capital: crítica da economia política. Livro I, volume 1. Rio de Janeiro: Civilização Brasileira. 2008a.

. Contribuição à crítica da economia política. São Paulo: Expressão Popular. 2008b.

2008c.

O Dezoito Brumário de Luís Bonaparte. São Paulo: Martin Claret.

Grundrisse: manuscritos econômicos de 1857-1858: esboços da crítica da economia política. São Paulo: Boitempo. 2011.

PRZEWORSKI, A. A social-democracia como fenômeno histórico. Revista Lua Nova [on-line], São Paulo, n. 15. 1988.

ROSDOLSKY, R. Gênese e estrutura de O capital de Karl Marx. Rio de Janeiro: Ed. Uerj/Contraponto. 2001.

ROWTHORN, B. Capitalismo, conflito e inflação. Ensaios de Economia Política. Rio de Janeiro: Zahar Editores. 1980.

THOMPSON, E. P. A formação da classe operária inglesa III: a força dos trabalhadores. Rio de Janeiro: Ed. Paz e Terra. 1987.

VIANNA, L. W. A classe operária e a abertura. São Paulo: Cerifa. 1983. 


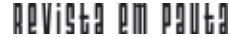

[ DA REPRESENTAÇÃO AO CONTROLE - PEÇANHA, V. L.\}

DOI: 10.12957/rep.2015.21051

Recebido em 31 de julho de 2015.

Aprovado para publicação em 20 de outubro de 2015.

DOI: 10.12957/rep.2015.21051

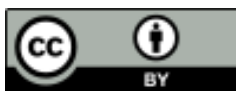

A Revista Em Pauta: Teoria Social e Realidade Contemporânea está licenciada com uma Licença Creative Commons Atribuição 4.0 Internacional. 